\title{
UMBELLIFERS AS POTENTIAL KEYSTONE SPECIES IN RESTORATION PROJECTS
}

\author{
Marcin Zych*, Pawel Niemczyk, Radosław Niemirski \\ University of Warsaw Botanic Garden, Aleje Ujazdowskie 4, 00-478 Warsaw, Poland \\ *mzych@biol.uw.edu.pl
}

Received: 17.09.2007

S u m m a r y

We studied visitation rates to four common European umbellifers: Angelica sylvestris, Anthriscus sylvestris, Daucus carota, and Heracleum sphondylium. Our observations and literature data confirm that a single plant species from the family Apiaceae may be visited by over a hundred insect taxa from taxonomically diverse groups. Here we suggest that in the light of pollination shortage faced by many endangered plant species, co-planting of relevant native Apiaceae plants, especially in Europe, should be taken into consideration in many restoration projects to provide, via umbelliferean magnet species, appropriate pollination service for focus plant taxa.

Key words: pollination, Apiaceae $=$ Umbelliferae, magnet species, endangered plants, biodiversity, allophilous plants

\section{INTRODUCTION}

In many continents numerous plant taxa become endangered and face extinction due to habitat loss, their populations become fragmented and increasingly smaller. To prevent this trend, nature conservation activities aim at stabilizing and expanding the size and number of such populations. Successful restoration is, however, limited by several environmental and biological factors. One being the pollination failure that may restrain natural regeneration of endangered plant populations ( $\mathrm{K} \mathrm{w} \mathrm{a} \mathrm{k}$ and $\mathrm{B} \mathrm{e} \mathrm{k} \mathrm{ke} \mathrm{r,} \mathrm{2006).} \mathrm{This} \mathrm{may} \mathrm{be} \mathrm{due}$ to pollinator shortage and/or the specialized nature of plant-pollinator relationships ( $\mathrm{Wilcock}$ and $\mathrm{Ne} \mathrm{i-}$ 1 and, 2002).

Umbellifers (species of the Apiaceae family) are visited by numerous insect pollinators from several taxonomic orders, usually providing the animals with pollen and nectar throughout the whole flowering period (Knuth, 1898; E11 is and E11 is-Adam, 1993; 1994; Z y c h, 2007). In the terminology of C o r bet (2006), they are allophilous plants (i.e. species with "flowers with fully exposed nectar and little or no intrafloral temperature elevation") that attract allotropous and hemitropous insects.

Many plants from this family are widely distributed throughout Europe and occur naturally in various plant communities. The above attributes make them good candidates for consideration in restoration projects as 'magnet species' attracting pollinators to plants of special care. Our aim was to examine the flower visitors to four common umbellifers growing in various habitats, in order to evaluate their use as such magnet plants in European conditions.

\section{MATERIALS AND METHODS}

We observed and captured flower visitors of two native European taxa of the family Apiaceae - Heracleum sphondylium and Angelica sylvestris. The former is widespread in forests and woodland clearings, riverbanks, and tall montane-herb grasslands ( $\mathrm{S}$ h e p p a rd, 1991). In Poland it is usually described as a common meadow species (G a w ł o w s k a, 1956), growing also in thickets, on roadsides and forest fringes ( $\mathrm{R} \mathrm{u} \mathrm{t} \mathrm{k} \mathrm{o} \mathrm{w} \mathrm{-}$ $\mathrm{s} \mathrm{k} \mathrm{i,} \mathrm{1998).} \mathrm{Its} \mathrm{geographical} \mathrm{range} \mathrm{includes} \mathrm{most} \mathrm{of} \mathrm{the}$ European countries, except the extreme north, parts of the Mediterranean region and some Atlantic and Mediterranean islands (B r u m it t, 1968; S h e p pard, 1991). Aneglica sylvestris is characteristic for wetlands, damp and shady places and is distributed almost throughout all Europe (Cannon, 1968). Both species are natural components of many plant communities in Europe.

The observations of $H$. sphondylium were carried in 2000 and 2002, in Wigry National Park (NE Poland, Suwałki district, Podlaskie voievodeship). The population was situated in the forest section 119, near the village of Krzywe (N 54 $05^{\prime}$ E $23^{\circ} 00^{\prime}$ ), and consisted of approx. 300 plants. The plants grew along the forest road in mixed spruce-pine forest. 
The observations in a large population of $A$. sylvestris (several thousand plants growing on the area of approx. 5 ha) were conducted in 2006 and 2007, in the wet meadows complex on the small Ruz river, in the vicinity of the village Kleczkowo (N 5302,9' E 21 ${ }^{\circ} 51,8^{\prime}$; NE Poland, Ostrołęka district, Mazowieckie voievodeship). The investigated community is rich in many endangered Polish Red Book plant species (e.g. Dactylorhiza incarnata, Dianthus superbus, and Polemonium caeruleum; $\mathrm{Zych}$ and $\mathrm{W}$ e r b l a n - J a k u b i e c, 2004, 2005). The plants grew in extensively used damp meadows on peat soils.

Each year the insects were captured in hourly schemes $(10 \mathrm{~min}$ capturing every hour, from 08.00 to 19.00 , during 4 days of the peak flowering period) using an entomological net or exhaustor, and killed in ethyl acetate for further identification. Every study day 12 rounds of capturings were conducted, but in case of strong winds or rain the observations were halted and the remaining rounds were completed at the corresponding hour on subsequent days, this adds to 48 plants being observed in each season in the case of either species. The plant used for a single capturing event was randomly selected and not excluded from the subsequent round of capturing, and therefore it was possible that the same umbel was observed more than once. Only primary umbels in full bloom, in either male or female phase, were chosen for capturing.

In both populations, we also randomly selected 50 plants to calculate the duration of the flowering period.

During literature survey we also extracted data on insect visitation to widespread European Apiaceae spe-

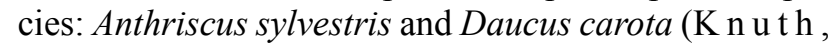
1898).

\section{RESULTS AND DISCUSSION}

The studied plants were visited by insects from eight taxonomic orders: Coleoptera, Diptera, Heteroptera, Hymenoptera, Lepidoptera, Mecoptera, Neuroptera, and Orthoptera (the list of insect taxa for H. sphondylium has already been published in $\mathrm{Z} \mathrm{y} \mathrm{ch} \mathrm{(2007),} \mathrm{and}$ for Anthriscus sylvestris and Daucus carota in K n u th (1898), the list for A. sylvestris is given in Tab. 1).

In all four cases, the 'core' of the flower visitors' assemblage was composed of Diptera, Hymenoptera and Coleoptera, which constituted $84-95 \%$ of the total entomofauna. We observed the largest pollinator assemblage for $H$. sphondylium. Its umbels were visited by 108 insect taxa (Fig. 1). This species was also the most attractive for 'Other' insect taxa (Heteroptera, Lepidoptera, Mecoptera, Neuroptera, and Orthoptera), which constituted $16 \%$ of its total entomofauna. In case of $H$. sphondy- lium and Angelica sylvestris, the highest proportion of visitors belonged to the order Diptera $(50 \%$ and $64 \%$, respectively), and in the case of Anthriscus sylvestris and Daucus carota, to Hymenoptera (35\% and $41 \%$, respectively).

The observations of flowering time of Angelica sylvestris and H. sphondylium showed that for both species, the flowering period for the population may extend over 6-10 weeks, and for the individual plant it lasts, on average, over 14 and 23 days, respectively in the case of H. sphondylium and A. sylvestris.

In many papers, plants of the family Apiaceae are shown to attract many insect visitors from various taxonomic groups (C o r b e t, 1970, 2006; G r a c e and Nelson, 1981; E1lis and Ellis-Adam, 1993; Ollerton et al. 2007; $\mathrm{Zych}, 2004,2007)$, this is also true for the taxa examined in the present paper. Flowers of each of the studied umbellifers were visited on average by 86 insect taxa from at least eight taxonomic orders; the list also includes specialized flower visitors. Most of the flower visitors belonged to the orders Hymenoptera and Diptera (Fig. 1, Tab. 1) regarded as groups of principal pollinators in the temperate regions (Proctor et al. 1996; Kearns, 2001; Larson et al. 2001).

The extended flowering period, due to continuous flowering of numerous inflorescences produced by an individual plant, provided insect visitors with foraging opportunities during a large part of the season (up to eight weeks in the case of populations of H. sphondylium and Angelica sylvestris). Being common European species that often naturally co-occur with rare and endangered species, such plants may act as catalysts of rare plants reproduction via attracting insects to less numerous plants of conservation interest. In one of the surveyed sites, for instance, the abundant population of Angelica sylvestris is visited by a group of insects also present on, and pollinators of, rare and endangered Polemonium caeruleum ( $\mathrm{Z}$ y c h, unpubl.).

In our opinion, the above-mentioned facts make the umbelliferean plants good candidates for 'magnetspecies' (T h o m s o n , 1978) with a potentially beneficial impact on pollinators' performance in communities where under-pollination may be expected. We encourage further studies on the role of umbellifers and other allophilous taxa (e.g. Asteraceae, Rosaceae or Ranunculaceae) in plant-pollinator networks as keystone species greatly affecting pollination services on the community level.

\section{Acknowledgments}

The project was supported by the Departmental Grant BW 1720/69 (to MZ) from Faculty of Biology, University of Warsaw. 


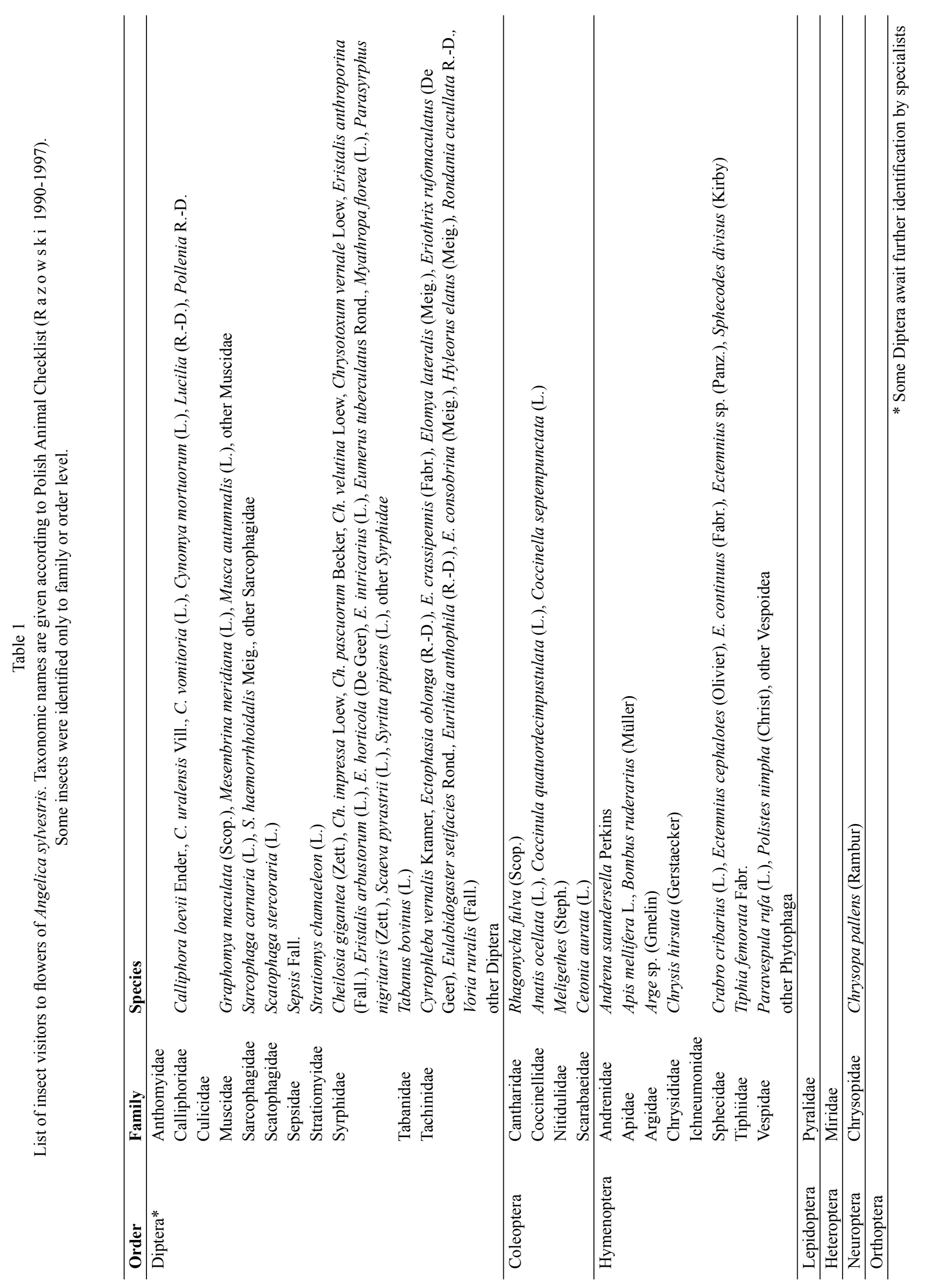




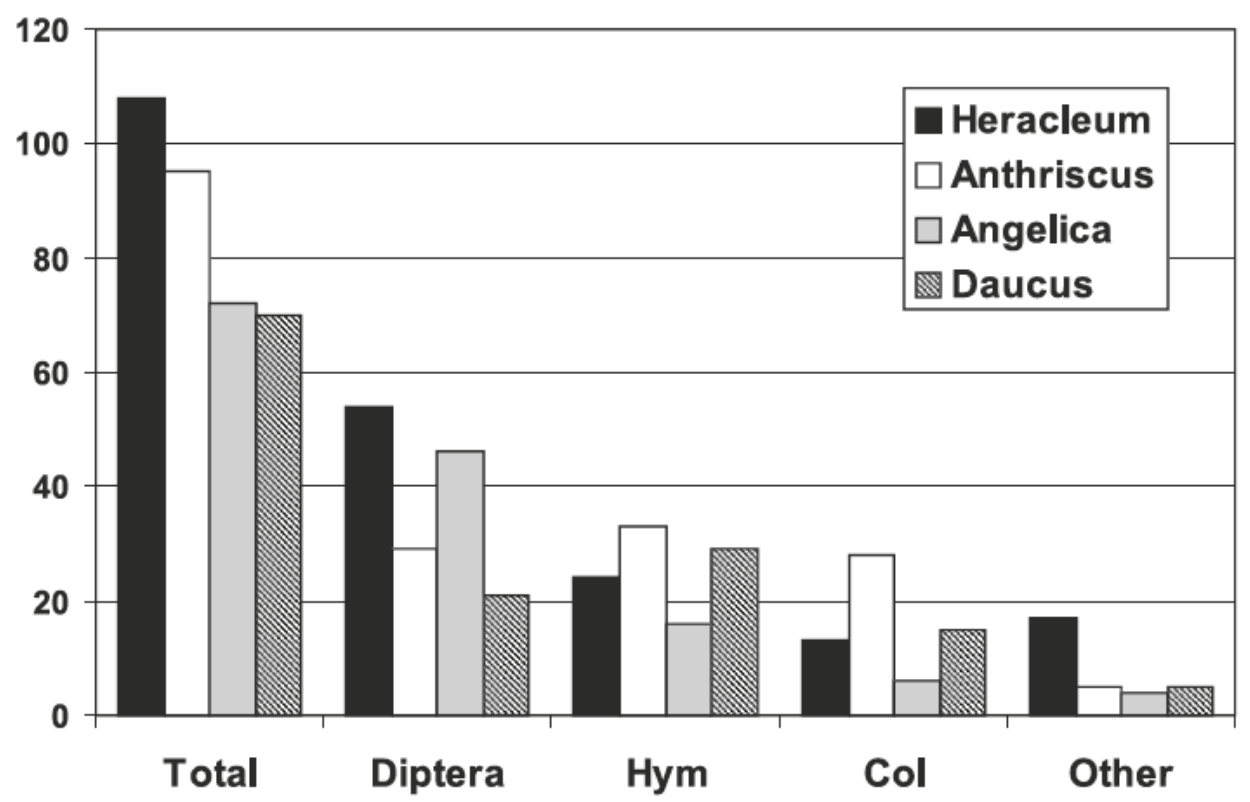

Fig. 1. Number of flower-visiting insect taxa to four widespread European Apiaceae species Heracleum sphondylium (Heracleum), Anthriscus sylvestris (Anthriscus), Angelica sylvestris (Angelica) and Daucus carota (Daucus). Data sources are indicated in Material and methods. Hym - Hymenoptera, Col - Coleoptera, 'Other' includes Lepidoptera, Heteroptera, Neuroptera, Orthoptera and Mecoptera.

\section{REFERENCES}

Brummitt R. K., 1968. Heracleum L. [In:] Flora Europaea vol. 2. Tutin T.G. et al. (eds.), Cambridge University Press, Cambridge, pp.364-366.

Cannon J. F. M., 1968. Angelica L. [In:] Flora Europaea vol. 2. Tutin T.G. et al. (eds.), Cambridge University Press, Cambridge, pp.357-358.

Corbet S. A., 1970. Insects on hogweed flowers: a suggestion for a student project. J. Biol. Edu. 4: 133-143.

Corbet S. A., 2006. A typology of pollination systems: implications for crop management and the conservation of wild plants. [In:] Plant-pollinator interactions. From specialization to generalization. Waser N.M., Ollerton J. (eds.), The University of Chicago Press, Chicago, pp.315-340.

Ellis W. N., Ellis-Ad am A. C., 1993. To make a meadow it takes a clover and a bee: the entomophilous flora of NW Europe and its insects. Bijdragen tot de Dierkunde, 63: 193-220.

Ellis W. N., Ellis-Adam A. C., 1994. Umbels are not alike. Entomol. Berich. Amsterdam, 54: 191-199.

Gawłowsk a M., 1956. Heracleum sphondylium L. and Heracleum sibiricum L. in Poland. Diss. Pharm. 7: 141-164.

Grace J., Nelson M., 1981. Insects and their pollen loads at a hybrid Heracleum site. New Phytol. 87: 413-423.

Kearns C. A., 2001. North American dipteran pollinators: assessing their value and conservation status. Cons. Ecol. 5(1): 5 .

Knuth P., 1898. Handbook of flower biology. Wilhelm Engelman, Leipizg.
Kwak M. M., Bekker R. M., 2006. Ecology of plant reproduction: extinction risks and restoration perspectives of rare plant species. [In:] Plant-pollinator interactions. From specialization to generalization. Waser N.M., Ollerton J. (eds.), The University of Chicago Press, Chicago, pp.362-386.

Larson B. M. H., Kevan P. G., Inouye D. W., 2001. Flies and flowers: taxonomic diversity of anthophiles and pollinators. Can. Entom. 133: 439-465.

Ollerton J., Killick A., Lamborn E., Watts S., Whiston M., 2007. Multiple meanings and modes: on the many ways to be a generalist flower. Taxon, 56: 717-728.

Proct or M., Yeo P., Lack A., 1996. Natural History of Pollination. Harper Collins, London.

Razowski J. (ed.), 1990-1997. Wykaz zwierząt Polski, t. 1-5. Wyd. Instytutu Systematyki i Ewolucji Zwierząt PAN, Kraków.

Rutkowski L., 1998. Klucz do oznaczania roślin naczyniowych Polski niżowej. Wydawnictwo Naukowe PWN, Warszawa.

Sheppard A.W., 1991. Heracleum sphondylium L. J. Ecol. 79: $235-258$.

Th om s on J.D., 1978. Effect of stand composition on insect visitation in two-species mixtures of Hieracium. Am. Mid. Nat. 100: 431-440.

Wilcock C., Neiland R., 2002. Pollination failure in plants: why it happens and when it matters. Tr. Plant Sci. 7: 270-277.

Zych M., 2004. Pollination biology of Apiaceae - old myths and new perspectives. Wiad. Bot. 48: 7-15. 
Zych M., 2007. On flower visitors and true pollinators: The case of protandrous Heracleum sphondylium L. (Apiaceae). Plant Syst. Evol. 263: 159-179.

Zych M., Werblan-Jakubiec H., 2004. A new, abundant locality of Polemonium caeruleum (Polemoniaceae) in the Mazovia region (NE Poland). Fragm. Flor. Geobot. Pol. 11: 400-402.

Zych M., Werblan-Jakubiec H., 2005. A new locality of Betula humilis (Betulaceae) in NE Mazovia (NE Poland). Fragm. Flor. Geobot. Pol. 12: 171-173.

\section{Baldaszkowate - potencjalne gatunki zwornikowe w projektach restytucyjnych}

\section{Streszczenie}

Celem pracy było ustalenie list kwiatowych gości dla czterech częstych europejskich gatunków roślin $\mathrm{z}$ rodziny baldaszkowatych (Apiaceae): Angelica sylvestris, Anthriscus sylvestris, Daucus carota i Heracleum sphondylium. Nasze obserwacje oraz dane literaturowe potwierdzaja, iż pojedyncza roślina $\mathrm{z}$ tej rodziny może być odwiedzana przez ponad sto taksonów owadów należących do wielu grup systematycznych. Sugerujemy zatem, iż w świetle doniesień o niedopyleniu wielu gatunków roślin, powinno rozważyć się stosowanie odpowiednio dobranych baldaszkowatych w wielu, zwłaszcza europejskich, projektach restytucyjnych. Umożliwi to, dzięki atraktantom wytwarzanym przez te „magnesowe” rośliny (magnet plants), zapewnienie stosownego poziomu zapyleń dla gatunków zagrożonych i ginących. 
